\title{
Study of the drying of mesocarp of baru (Dipteryx alata Vogel) fruits
}

\author{
Pâmella M. de Oliveira ${ }^{1}$, Daniel E. C. de Oliveira ${ }^{2}$, Osvaldo Resende ${ }^{3}$ \& Daiana V. Silva ${ }^{1}$ \\ ${ }^{1}$ Instituto Federal de Educação, Ciência e Tecnologia Goiano/Campus Rio Verde. Rio Verde, GO. E-mail: ompamella@gmail.com - ORCID: 0000-0001- \\ 7610-2036; daianadally@hotmail.com - ORCID: 0000-0001-9207-5875 \\ ${ }^{2}$ Instituto Federal de Educação, Ciência e Tecnologia Goiano/Campus Iporá. Iporá, GO. E-mail: oliveira.d.e.c@gmail.com (Corresponding author) - \\ ORCID: 0000-0002-3824-994X \\ ${ }^{3}$ Instituto Federal de Educação, Ciência e Tecnologia Goiano/Diretoria de Pesquisa e Pós-Graduação/Campus Rio Verde. Rio Verde, GO. E-mail: \\ osvresende@yahoo.com.br - ORCID: 0000-0001-5089-7846
}

\section{Key words:}

moisture content

color analysis

thermodynamic properties

\begin{abstract}
A B S T R A C T
Baru (Dipteryx alata Vogel) is a tree species that is part of the group of native species of the Cerrado and occurs mainly in Central Brazil, being valued for its various uses. Thus, the present work was carried out with the objective of studying the kinetics of drying of the mesocarp of baru fruits, performing the analysis of the thermodynamic properties, as well as evaluating the effect of drying on the color of the flour produced from the mesocarp. The mesocarp of baru fruits was placed in stainless steel trays, and dried at $40,50,60$ and $70{ }^{\circ} \mathrm{C}$ in a forced circulation oven until the moisture content of 0.12 dry basis (d.b.) was reached. Subsequently, the experimental data of the drying were adjusted with the mathematical models frequently used, and color was evaluated after the drying. It is concluded that the Wang \& Singh model was selected to represent the drying curves of the baru mesocarp. For the thermodynamic properties, with increasing drying air temperature, the entropy and enthalpy values decreased while the Gibbs free energy increased. Regarding color, the results showed that with the increase of drying air temperature, there is a change in color, which indicates loss in the qualitative aspect.
\end{abstract}

\section{Palavras-chave:}

teor de água

análise de cor

propriedades termodinâmicas

\section{Estudo da secagem do mesocarpo dos frutos de baru (Dipteryx alata Vogel)}

\section{R E S U M O}

O baru (Dipteryx alata Vogel) é uma espécie arbórea que faz parte do grupo de espécies nativas do cerrado, e ocorre principalmente no Brasil Central, sendo valorizada por suas diversas utilizações. O presente trabalho foi conduzido com o objetivo de estudar a cinética de secagem do mesocarpo dos frutos de baru, realizar a análise das propriedades termodinâmicas, bem como avaliar o efeito da secagem na cor da farinha produzida a partir do mesocarpo. O mesocarpo dos frutos de baru foi disposto em bandejas de aço inox e submetido à secagem a 40,50,60 e $70{ }^{\circ} \mathrm{C}$ em estufa com circulação forçada até atingir o teor de água de 0,12 base seca (b.s.). Posteriormente, os dados experimentais da secagem foram ajustados aos modelos matemáticos frequentemente utilizados, e após a secagem, foi avaliada a cor. Concluiu-se que o modelo Wang e Singh foi selecionado para representar as curvas de secagem do mesocarpo de baru. Para as propriedades termodinâmicas, com o aumento da temperatura do ar de secagem, os valores de entropia e entalpia decrescem, enquanto a energia livre de Gibbs aumenta. Quanto à cor, os resultados apresentaram que com o aumento da temperatura do ar de secagem, ocorre alteração na cor, indicando perda no aspecto qualitativo. 


\section{INTRODUCTION}

Baru (Dipteryx alata Vogel) belongs to the Fabaceae family, occurring in the most fertile soils of the Cerrado, and is a tall tree, reaching up to $15 \mathrm{~m}$ in height, with an erect stem and smooth branches (Correa et al., 2008). Also known as, 'cumbaru', 'barujo, 'coco bean', 'embunera brava' and 'cumaru', the baru tree has fruits with pulp and almond used in human food (Sano et al., 2004).

The chemical composition of baru epicarp and mesocarp arouses technological interest, due to its composition with high levels of starch, insoluble fiber and sugars, besides being rich in vitamins and minerals such as potassium, copper, iron, calcium, phosphorus and magnesium (Rocha \& Santiago, 2009).

One way to reduce the post-harvest losses of baru is the drying process, which, in addition to being economical, provides an increase in shelf life and ease of transportation and commercialization, since products submitted to this process have a lighter weight if compared to its initial state, due to the reduction of moisture content (Celestino, 2010).

Costa et al. (2016) point out that drying is a process that must be well understood to achieve technical and economic efficiencies. Baptestini et al. (2016) indicate that drying prolongs the shelf life of food, thus reducing microbiological deterioration and degradation reactions, as well as facilitating the handling and consumption of the fruits.

In the literature there is limited information regarding the processing of the mesocarp of baru fruits. The objective of this work was to study the drying kinetics of the mesocarp of baru fruits, to perform the analysis of the thermodynamic properties, as well as to evaluate the effect of drying on the color of the flour produced from the mesocarp.

\section{Material AND Methods}

The fruits used were collected in baru trees located in the municipality of Santa Helena de Goiás, GO, Brazil, at $17^{\circ} 48^{\prime} \mathrm{S}$, $50^{\circ} 35^{\prime} \mathrm{W}$ and altitude of $568 \mathrm{~m}$. The fruits were harvested on the ground and selected according to the integrity of the pericarp. Subsequently, the fruits were taken to the Laboratory of Postharvest of Plant Products of the Federal Institute of Goiás (IF Goiano), located in the municipality of Rio Verde, Goiás.

Four 1-kg portions of baru fruits were weighed and then washed with a soft bristle brush and distilled water and submitted to the sanitization process, as described by Medeiros et al. (2010). The samples were sanitized in tanks with chlorinated water at $150 \mathrm{ppm}$, where they remained for $15 \mathrm{~min}$, and then washed in running water to remove residual chlorine.

Due to the hardness of the fruits, they were placed in beakers containing $1.3 \mathrm{~L}$ of distilled water, where they were immersed for $18 \mathrm{~h}$. After this process, baru mesocarp was removed manually with the aid of a previously sanitized stainless steel knife. After removal, the samples were placed on trays and submitted to the drying process in a forced ventilation oven under different temperature conditions, 40, 50, 60 and $70{ }^{\circ} \mathrm{C}$, which provided the relative humidity of $24.00,11.54$, 8.41 and $4.81 \%$, respectively. Mesocarp drying was performed in unperforated trays containing $100 \mathrm{~g}$ of product, $2 \mathrm{~cm}$ thick, in a completely randomized design in three replicates.

To determine the drying curves, the final moisture content of 0.12 dry basis (d.b.) was established. The moisture contents of the product were determined in an oven at $105 \pm 1{ }^{\circ} \mathrm{C}$ until constant mass.

To determine the moisture content ratios of the mesocarp of baru fruits during drying, the following expression was used:

$$
\mathrm{MR}=\frac{\mathrm{M}-\mathrm{M}_{\mathrm{e}}}{\mathrm{M}_{\mathrm{i}}-\mathrm{M}_{\mathrm{e}}}
$$

where:

MR - moisture content ratio of the product, dimensionless;

M - moisture content of the product, d.b.;

$\mathrm{M}_{\mathrm{i}} \quad$ - initial moisture content of the product, d.b.; and,

$M_{e}$ - equilibrium moisture content of the product, d.b.

The experimental data of the drying of the mesocarp of baru fruits were fitted with the mathematical models frequently used to represent the drying of agricultural products, as shown in Table 1.

Table 1. Mathematical models used to predict the drying of agricultural products

\begin{tabular}{|c|c|c|}
\hline Model designation & Model & \\
\hline$M R=1+a \cdot t+b \cdot t^{2}$ & Wang \& Sing & (2) \\
\hline$M R=a \cdot \exp (-k \cdot t)+(1-a) \exp \left(-k_{1} \cdot t\right)$ & Verma & (3) \\
\hline$M R=\exp \left\{\left[-a-\left(a^{2}+4 \cdot b \cdot t\right)^{0.5}\right] / 2 \cdot b\right\}$ & Thompson & $(4)$ \\
\hline$M R=\exp \left(-k \cdot t^{n}\right)$ & Page & (5) \\
\hline$M R=\exp (-k \cdot t)$ & Newton & $(6)$ \\
\hline$M R=a \cdot \exp \left(-k \cdot t^{n}\right)+b \cdot t$ & Midilli & (7) \\
\hline$M R=a \cdot \exp (-k \cdot t)+c$ & Logarithmic & (8) \\
\hline$M R=a \cdot \exp (-k \cdot t)$ & Henderson \& Pabis & (9) \\
\hline$M R=a \cdot \exp (-k \cdot t)+(1-a) \exp (-k \cdot a \cdot t)$ & Two-term exponential & (10) \\
\hline$M R=a \cdot \exp \left(-k_{0} \cdot t\right)+b \cdot \exp \left(-k_{1} \cdot t\right)$ & Two terms & (11) \\
\hline$M R=a \cdot \exp (-k \cdot t)+(1-a) \cdot \exp (-k \cdot b \cdot t)$ & Approximation of diffusion & (12) \\
\hline
\end{tabular}

The mathematical models were fitted by non-linear regression analysis using the Gauss-Newton method. The models were selected considering the magnitude of the coefficient of determination $\left(\mathrm{R}^{2}\right)$, the chi-square test $\left(\chi^{2}\right)$, the relative mean error $(\mathrm{P})$ and the estimated mean error (SE), according to Costa et al. (2015).

To describe the net diffusion, the infinite drum geometric shape model of the "flour flakes" was used, with the approximation of eight terms.

$$
\mathrm{MR}=\frac{\mathrm{M}-\mathrm{M}_{\mathrm{e}}}{\mathrm{M}_{\mathrm{i}}-\mathrm{M}_{\mathrm{e}}}=\sum_{\mathrm{n}_{\mathrm{t}}=1}^{\infty} \frac{4}{\lambda_{\mathrm{n}_{\mathrm{t}}}^{2}} \exp \left[-\frac{\lambda_{\mathrm{n}_{\mathrm{t}}}^{2} \mathrm{Dt}}{4}\left(\frac{2}{\mathrm{r}}\right)^{2}\right]
$$

where:

$\mathrm{n}_{\mathrm{t}} \quad$ - number of terms;

D - coefficient of diffusion, $\mathrm{m}^{2} \mathrm{~s}^{-1}$;

$r$ - equivalent radius, $m$;

$\lambda_{n} \quad$ - roots of the zero-order Bessel equation; and,

$\mathrm{t} \quad$ - drying time, s.

The equivalent radius of the flakes were determined by the following expression: 


$$
r=\sqrt[3]{\frac{3 V_{f}}{4 \pi}}
$$

where:

$\mathrm{V}_{\mathrm{f}} \quad$ - flakes volume, $\mathrm{m}^{-3}$.

The volume of the "flakes" $\left(\mathrm{V}_{\mathrm{f}}\right)$ was obtained by measuring the three orthogonal axes (length, width and thickness) in fifteen units of "flakes" of the mesocarp meal of the baru fruits, with the aid of a digital caliper.

$$
\mathrm{V}_{\mathrm{f}}=\frac{\pi \mathrm{ABC}}{6}
$$

where:

$$
\begin{array}{ll}
\text { A } & \text { - length, m; } \\
\text { B } & \text { - width, m; and, } \\
\text { C } & \text { - thickness, m. }
\end{array}
$$

The relationship between the effective diffusion coefficient and the drying air temperature elevation was described by the Arrhenius equation.

$$
\mathrm{D}=\mathrm{D}_{\mathrm{o}} \exp \left(\frac{-\mathrm{E}_{\mathrm{a}}}{\mathrm{R} \mathrm{T}_{\mathrm{abs}}}\right)
$$

where:

$\mathrm{D}_{\mathrm{O}}$ - pre-exponential factor;

$\mathrm{E}_{\mathrm{a}} \quad$ - activation energy, $\mathrm{kJ} \mathrm{mol}^{-1}$;

$\mathrm{R}$ - universal constant of gases, $8.134 \mathrm{~kJ} \mathrm{kmol}^{-1} \mathrm{~K}^{-1}$; and,

$\mathrm{T}_{\mathrm{abs}}$ - Absolute temperature, $\mathrm{K}$.

The thermodynamic properties (enthalpy, entropy and Gibbs free energy) of baru mesocarp drying were obtained by the method described by Jideani \& Mpotokwana (2009):

$$
\begin{gathered}
\mathrm{H}=\mathrm{E}_{\mathrm{a}}-\mathrm{RT} \\
\mathrm{S}=\mathrm{R}\left(\ln \mathrm{k}-\ln \frac{\mathrm{k}_{\mathrm{B}}}{\mathrm{h}_{\mathrm{p}}}\right)-\ln \mathrm{T}_{\mathrm{abs}} \\
\mathrm{G}=\mathrm{H}-\mathrm{T}_{\mathrm{abs}} \mathrm{S}
\end{gathered}
$$

where:

$$
\begin{array}{ll}
\mathrm{H} & \text { - enthalpy, } \mathrm{J} \mathrm{mol}^{-1} \text {; } \\
\mathrm{S} & \text { - entropy, } \mathrm{J} \mathrm{mol}^{-1} \text {; } \\
\mathrm{G} & \text { - Gibbs free energy, } \mathrm{J} \mathrm{mol}^{-1} \text {; } \\
\mathrm{kB} & - \text { Boltzmann constant, } 1.38 \times 10^{-23} \mathrm{~J} \mathrm{~K}^{-1} \text {; and, } \\
\mathrm{hp} & - \text { Planck constant, } 6.626 \times 10^{-34} \mathrm{~J} \mathrm{~s}^{-1} \text {. }
\end{array}
$$

The determination of the color of the mesocarp of the baru fruits after drying was carried out by means of a colorimeter, which evaluates color attributes by the system of the International Commission on Illumination (CIELAB). Color analysis was performed in fifteen replicates for each drying condition, the data were submitted to analysis of variance and the averages were compared by Tukey test at $5 \%$ significance level using SISVAR 'statistical software (Ferreira, 2011).

\section{Results AND Discussion}

For the estimated mean error (SE), all models had low values close to zero, which makes the results relevant due to the good adjustment of the models to the experimental data (Table 2). In general, the Logarithmic, Midilli, Diffusion Approximation and Verma models showed the lowest values of SE, whereas the Thompson, Two-Term Exponential and Newton models showed higher values.

For the chi-square $\left(\chi^{2}\right)$ values, all the analyzed models had relevant values, being smaller than the tabulated value (12.838). In this case, the models with the lowest chi-square values among the eleven were: Logarithmic, Midilli, Approximation of diffusion and Verma. For the temperature of $60^{\circ} \mathrm{C}$, the Wang \& Sing model showed smaller value.

All the mathematical models had coefficients of determination $\left(\mathrm{R}^{2}\right)$ superior to 0.99 , except the models Thompson, Newton and Two-term exponential, which indicates a situation that satisfies satisfactorily the drying process. However, the $\mathrm{R}^{2}$ value alone is not a good parameter for selecting nonlinear models because it uses the mean of negative and positive values, which can leave the more extreme values out of the analysis.

For the relative mean error (P), the Thompson, Newton, Page, Henderson \& Pabis and Two-term exponential models did not show satisfactory results for temperatures of 40 and $50{ }^{\circ} \mathrm{C}$, with values higher than $10 \%$ and not suitable to represent the phenomenon (Mohapatra \& Rao, 2005).

From the analysis of the statistical parameters, it was verified that, with the exception of the Thompson, Newton, Page, Henderson \& Pabis and Two-term exponential models, which are not suitable, the other models showed good adjustment to the experimental data. It is possible to select the Wang \& Singh model to represent the drying phenomenon of baru mesocarp due to its greater simplicity of application. Sousa et al. (2016) and Smaniotto et al. (2017), indicated the same model to represent the drying curve of malt bagasse and sunflower grains, respectively.

The drying times of the mesocarp of baru fruits at temperatures of $40,50,60$ and $70^{\circ} \mathrm{C}$ decreased with increasing drying temperature, thus showing a higher water withdrawal rate (Figure 1). This drying behavior was similar to those of most agricultural products (Costa et al., 2015, Sousa et al., 2017).

It was observed that at higher temperatures, the decrease of the moisture content ratio occurred in a shorter period of time and, as the temperature dropped occurred, more time was required for water to be removed. Thus, it was possible to observe in Figure 1 that the temperature of $70{ }^{\circ} \mathrm{C}$ required $3 \mathrm{~h}$ to achieve approximately 0.12 dry basis (d.b.) of moisture content, whereas for the temperature of $40{ }^{\circ} \mathrm{C}$ it was necessary approximately $7 \mathrm{~h}$ to reach the same value of moisture content.

The effective diffusion coefficient of the mesocarp of baru fruits increased proportionally to the increase of the drying air temperature (Figure 2), showing a behavior similar to that of other products: niger seeds (Silva et al., 2017), sunflower seeds (Smaniotto et al., 2017) and 'pequi' pulp (Sousa et al., 2017). 
Table 2. Values for estimated mean error (SE, decimal), Chi-square test $\left(\chi^{2}\right.$, decimal), determination coefficients $\left(R^{2}\right)$ and relative mean error $(\mathrm{P}, \%)$ for the eleven representations of the drying kinetics of the mesocarp Baru (Dipteryx alata Vogel) fruits

\begin{tabular}{|c|c|c|c|c|c|c|c|c|}
\hline \multirow{2}{*}{ Model } & \multicolumn{4}{|c|}{$40^{\circ} \mathrm{C}$} & \multicolumn{4}{|c|}{$50^{\circ} \mathrm{C}$} \\
\hline & SE & $\overline{\chi^{2}}$ & $\mathrm{R}^{2}$ & $\bar{P}$ & SE & $\overline{\chi^{2}}$ & $\mathrm{R}^{2}$ & $\mathbf{P}$ \\
\hline Wang \& Sing & 0.0227 & 0.00052 & 0.9954 & 6.999 & 0.0157 & 0.00025 & 0.9976 & 5.146 \\
\hline Verma & 0.0171 & 0.00029 & 0.9975 & 5.656 & 0.0105 & 0.00011 & 0.9990 & 4.473 \\
\hline Thompson & 0.0300 & 0.00090 & 0.9919 & 18.726 & 0.0314 & 0.00099 & 0.9905 & 22.858 \\
\hline Page & 0.0251 & 0.00063 & 0.9944 & 12.015 & 0.0220 & 0.00049 & 0.9953 & 13.484 \\
\hline Newton & 0.0290 & 0.00084 & 0.9919 & 18.722 & 0.0302 & 0.00091 & 0.9905 & 22.854 \\
\hline Midilli & 0.0154 & 0.00024 & 0.9982 & 6.722 & 0.0112 & 0.00013 & 0.9990 & 5.995 \\
\hline Logarithmic & 0.0143 & 0.00020 & 0.9983 & 6.937 & 0.0100 & 0.00010 & 0.9991 & 5.941 \\
\hline Henderson \& Pabis & 0.0299 & 0.00089 & 0.9920 & 18.385 & 0.0302 & 0.00091 & 0.9913 & 21.381 \\
\hline Two-term exponential & 0.0300 & 0.00090 & 0.9919 & 18.722 & 0.0314 & 0.00099 & 0.9905 & 22.854 \\
\hline Two terms & 0.0188 & 0.00035 & 0.9972 & 8.129 & 0.0097 & 0.00009 & 0.9992 & 5.098 \\
\hline \multirow[t]{3}{*}{ Approximation of diffusion } & 0.0171 & 0.00029 & 0.9975 & 5.658 & 0.0105 & 0.00011 & 0.9990 & 4.473 \\
\hline & \multicolumn{4}{|c|}{$60^{\circ} \mathrm{C}$} & \multicolumn{4}{|c|}{$70^{\circ} \mathrm{C}$} \\
\hline & SE & $\overline{\chi^{2}}$ & $\mathbf{R}^{2}$ & $\mathbf{P}$ & SE & $\overline{\chi^{2}}$ & $\mathbf{R}^{2}$ & $\mathbf{P}$ \\
\hline Wang \& Sing & 0.0075 & 0.00006 & 0.9995 & 3.453 & 0.0150 & 0.00023 & 0.9979 & 4.214 \\
\hline Verma & 0.0187 & 0.00035 & 0.9972 & 9.943 & 0.0130 & 0.00017 & 0.9985 & 3.362 \\
\hline Thompson & 0.0382 & 0.00146 & 0.9872 & 20.664 & 0.0267 & 0.00071 & 0.9932 & 10.674 \\
\hline Page & 0.0124 & 0.00015 & 0.9986 & 4.183 & 0.0155 & 0.00024 & 0.9977 & 4.488 \\
\hline Newton & 0.0366 & 0.00134 & 0.9872 & 20.662 & 0.0254 & 0.00065 & 0.9932 & 10.671 \\
\hline Midilli & 0.0107 & 0.00011 & 0.9992 & 3.041 & 0.0140 & 0.00020 & 0.9985 & 3.165 \\
\hline Logarithmic & 0.0192 & 0.00037 & 0.9971 & 9.979 & 0.0137 & 0.00019 & 0.9984 & 3.831 \\
\hline Henderson \& Pabis & 0.0327 & 0.00107 & 0.9906 & 17.056 & 0.0245 & 0.00060 & 0.9943 & 9.400 \\
\hline Two-term exponential & 0.0382 & 0.00146 & 0.9872 & 20.662 & 0.0267 & 0.00071 & 0.9932 & 10.671 \\
\hline Two terms & 0.0102 & 0.00010 & 0.9993 & 3.509 & 0.0138 & 0.00019 & 0.9985 & 3.358 \\
\hline Approximation of diffusion & 0.0187 & 0.00035 & 0.9972 & 9.943 & 0.0130 & 0.00017 & 0.9985 & 3.362 \\
\hline
\end{tabular}

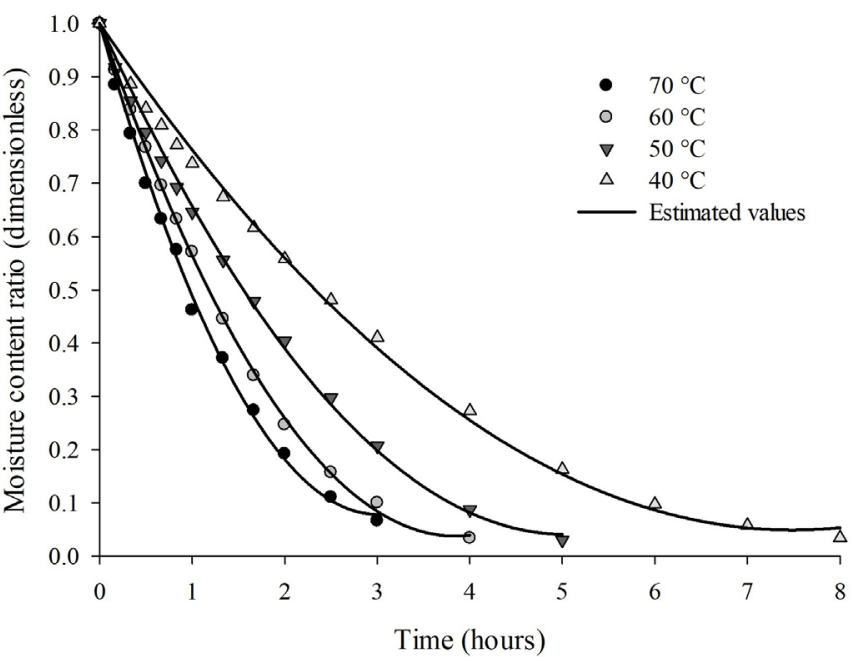

Figure 1. Experimental moisture content ratio values estimated by the Wang \& Singh model for the drying of the mesocarp of baru (Dipteryx alata Vogel) fruits under different temperature conditions

It was observed that the linear model satisfactorily represented the experimental data, with determination coefficient $\mathrm{R}^{2}=0.9986$, demonstrating that the diffusivity depends on the drying air temperature and that the higher the temperature of the drying air, the greater the diffusivity, thus compromising the resistance of the mesocarp of baru fruits to the removal of water.

The activation energy found for the drying phenomenon of the mesocarp of baru fruits was $27.005 \mathrm{~kJ} \mathrm{~mol}^{-1}$. Souza et al. (2014) conducted works with pequi where the activation energy ranged from 27.21 to $41.30 \mathrm{~kJ} \mathrm{~mol}^{-1}$, while Siqueira et al. (2012), in studies on effective diffusivity with jatropha fruits, reported activation energy of $23.88 \mathrm{~kJ} \mathrm{~mol}^{-1}$; this is

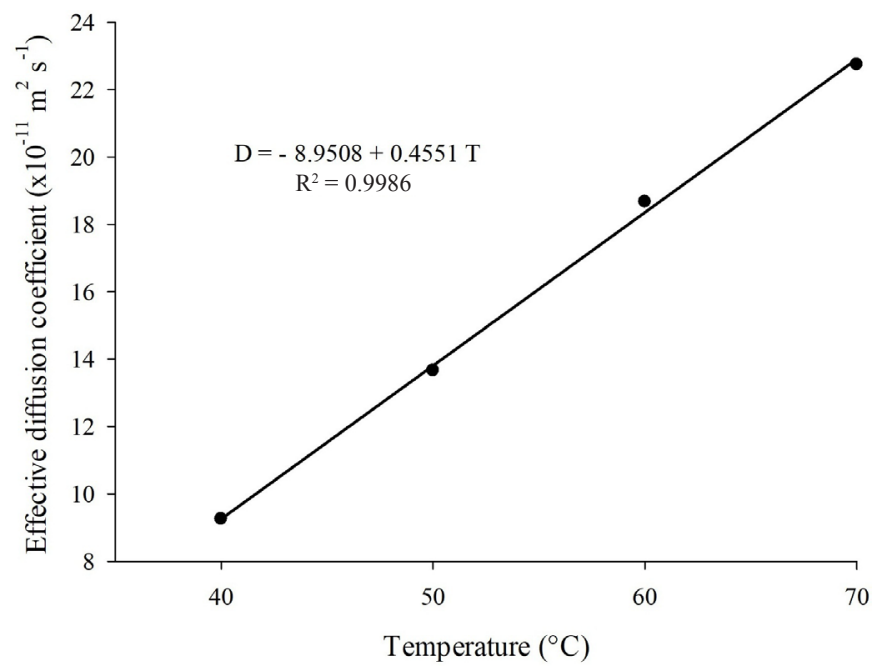

Figure 2. Effective diffusion coefficient obtained for the drying of the mesocarp of baru (Dipteryx alata Vogel) fruits at temperatures of $40,50,60$ and $70{ }^{\circ} \mathrm{C}$

due to the fact that the products which have higher moisture content and more unstable bonds with water can have lower values of activation energy. According to Corrêa et al. (2007), the activation energy indicates the ease with which the water molecules overcome the energy barrier in the movement inside the product, and the smaller the activation energy, the greater the water diffusivity in the product.

In Table 3 it can be seen that, in the variation of the enthalpy values, the higher the temperature of the drying air the lower the $\mathrm{H}$ value, the same way with the entropy behavior.

For Goneli et al. (2010), entropy is a thermodynamic quantity that is related to the degree of disorder, where the values increase in the natural process in an isolated system. Negative values of entropy can be attributed to structural 
Table 3. Values of enthalpy $(\mathrm{H})$, entropy $(\mathrm{S})$, Gibbs free energy $(\mathrm{G})$ and the coordinates $\mathrm{L}$, $\mathrm{a}^{*}$ and $\mathrm{b}^{*}$ for different conditions of the drying air in the drying of the mesocarp of baru (Dipteryx alata Vogel) fruits

\begin{tabular}{|c|c|c|c|c|c|c|}
\hline \multirow{2}{*}{$\begin{array}{c}\text { Temperature } \\
\left({ }^{\circ} \mathrm{C}\right)\end{array}$} & \multicolumn{3}{|c|}{ Thermodynamic properties } & \multicolumn{3}{|c|}{ Coordinates } \\
\hline & $\mathrm{H}\left(\mathrm{J} \mathrm{mol}^{-1}\right)$ & $\mathrm{S}\left(\mathrm{J} \mathrm{mol}^{-1} \mathrm{~K}^{-1}\right)$ & $\mathrm{G}\left(\mathrm{J} \mathrm{mol}^{-1}\right)$ & $\bar{L}$ & $a^{*}$ & $b^{*}$ \\
\hline 40 & 24401.17 & -139.76 & 68167.02 & $52.00 \mathrm{a}$ & $7.26 \mathrm{a}$ & $30.41 a$ \\
\hline 50 & 24318.03 & -140.02 & 69565.93 & $53.19 \mathrm{a}$ & $7.15 \mathrm{a}$ & $30.37 a$ \\
\hline 60 & 24234.89 & -140.27 & 70967.42 & $51.07 \mathrm{ab}$ & $6.66 \mathrm{a}$ & $27.98 b$ \\
\hline 70 & 24151.75 & -140.52 & 72371.40 & $46.13 b$ & $9.06 \mathrm{~b}$ & $28.48 b$ \\
\hline
\end{tabular}

Means followed by the same letter in the column do not differ from each other, according to Tukey's test, at 0.05 significance level

modifications and to the existence of chemical adsorption

(Moreira et al., 2008).

For the Gibbs free energy, there was an increase in the values with the increase of the temperature of the drying air. Gibbs free energy is related to and attributed to the work that is required to make sorption sites available. For this, the positive values for the Gibbs free energy indicate that the drying of the mesocarp of baru fruits was not a process that occurred spontaneously, corroborating with the results obtained by Corrêa et al. (2010) for coffee fruits.

Still in Table 3, it was verified that the increase of the drying temperature caused alteration in the color of the mesocarp of baru fruits. For the coordinate L, which refers to the luminosity, varying between black and white colors, at temperatures of 40 and $50^{\circ} \mathrm{C}$, the values differed from those at temperature of $70^{\circ} \mathrm{C}$, and the values decreased with increasing temperature. Thus, at the temperature of $70{ }^{\circ} \mathrm{C}$ there was darkening of the mesocarp of the baru fruits.

Regarding the coordinate $\mathrm{a}^{*}$, which indicates the chromaticity by means of the green and red colors, the temperatures of 40,50 and $60^{\circ} \mathrm{C}$ differed from the temperature of $70{ }^{\circ} \mathrm{C}$; at the temperature of $70{ }^{\circ} \mathrm{C}$, the mesocarp of baru fruits appeared more reddish. As for the $\mathrm{b}^{*}$ coordinate, which varies between yellow and blue, temperatures of 40 and $50^{\circ} \mathrm{C}$ differed from temperatures of 60 and $70^{\circ} \mathrm{C}$. With the increase of drying air temperature, the color of the mesocarp tended to be dark yellow. Thus, the increase in drying temperature promoted a change in color, with the temperature of $50^{\circ} \mathrm{C}$ being indicated for drying, since it did not differ from the temperature of $40^{\circ} \mathrm{C}$ and the drying time was shorter. Oliveira et al. (2017), studying the effect of drying on the color of baru fruits, indicated the temperature of $60^{\circ} \mathrm{C}$.

\section{Conclusions}

1. The Wang \& Singh, Verma, Midilli, Logarithmic, Two-Term and Diffusion Approximation models show good adjustment to the experimental data, and the Wang \& Singh model was selected to represent baru mesocarp drying kinetics.

2. The thermodynamic properties are influenced by the drying temperature. The increase in the drying temperature promotes a change in color, with the temperature of $50{ }^{\circ} \mathrm{C}$ being indicated for drying.

\section{ACKNOWLEDGements}

The authors extend thanks to IF Goiano, CAPES, FAPEG, FINEP and CNPq for their financial support, which was indispensable for the execution of this study.

\section{Literature Cited}

Baptestini, F. M.; Corrêa, P. C.; Oliveira, G. H. H.; Almeida, L. F. J.; Vargas-Elías, G. A. Constant and decreasing periods of pineapple slices dried by infrared. Revista Brasileira de Ciências Agrárias, v.11, p.53-59, 2016. https://doi.org/10.5039/agraria.v11ila5160

Celestino, S. M. C. Princípios de secagem de alimentos. 1.ed. Planaltina: Embrapa Cerrados, 2010. 51p.

Correa, G. de C.; Naves, R. V.; Rocha, M. R. da; Chaves, L. J.; Borges, J. D. Determinações físicas em frutos e sementes de baru (Dipteryx alata Vog.), cajuzinho (Anacardium othonianum Rizz.) e pequi (Caryocar brasiliense Camb.), visando melhoramento genético. Bioscience Journal, v.24, p.42-47, 2008.

Corrêa, P. C.; Oliveira, G. H. H.; Botelho, F. M.; Goneli, A. L. D.; Carvalho, F. M. Modelagem matemática e determinação das propriedades termodinâmicas do café (Coffea arabica L.) durante o processo de secagem. Revista Ceres, v.57, p.595-601, 2010. https://doi.org/10.1590/S0034-737X2010000500005

Corrêa, P. C.; Resende, O.; Martinazzo, A. P.; Goneli, A. L. G.; Botelho, F. M. Modelagem matemática para a descrição do processo de secagem do feijão (Phaseolus vulgaris L.) em camadas delgadas. Engenharia Agrícola, v.27, p.501-510, 2007. https://doi. org/10.1590/S0100-69162007000300020

Costa, C. F.; Corrêa, P. C.; Vanegas, J. D. B.; Baptestini, F. M.; Campos, R. C.; Fernandes, L. S. Mathematical modeling and determination of thermodynamic properties of jabuticaba peel during the drying process. Revista Brasileira de Engenharia Agrícola e Ambiental, v.20, p.576-580, 2016. https://doi.org/10.1590/1807-1929/ agriambi.v20n6p576-580

Costa, L. M.; Resende, O.; Gonçalves, D. N.; Oliveira, D. E. C. de. Modelagem matemática da secagem de frutos de crambe em camada delgada. Bioscience Journal, v.31, p.392-403, 2015. https:// doi.org/10.14393/BJ-v31n2a2015-22340

Ferreira, D. F. Sisvar: A computer statistical analysis system. Ciência e Agrotecnologia, v.35, p.1039-1042, 2011. https://doi.org/10.1590/ S1413-70542011000600001

Goneli, A. L. D.; Corrêa, P. C.; Oliveira, G. H. H.; Botelho, F. M. Water desorption and thermodynamic properties of okra seeds. Transactions of the American Society of Agricultural Engineers, v.53, p.191-197, 2010.

Jideani, V. A.; Mpotokwana, S. M. Modeling of water absorption of Botswana bambara varieties using Peleg's equation. Journal of Food Engineering, v.92, p.182-188, 2009. https://doi. org/10.1016/j.jfoodeng.2008.10.040

Medeiros, M. J.; Oliveira, P. A. A. C. de; Souza, J. M. L. de; Silva, R. F. da; Souza, M. L. de. Composição química de misturas de farinhas de banana verde com castanhado-brasil. Revista Instituto Adolfo Lutz, v.69, p.396-402, 2010.

Mohapatra, D.; Rao, P. S. A thin layer drying model of parboiled wheat. Journal of Food Engineering, v.66, p.513-518, 2005. https://doi. org/10.1016/j.jfoodeng.2004.04.023 
Moreira, R.; Chenlo, F.; Torres, M. D.; Vallejo, N. Thermodynamic analysis of experimental sorption isotherms of loquat and quince fruits. Journal of Food Engineering, v.88, p.514-521, 2008. https:// doi.org/10.1016/j.jfoodeng.2008.03.011

Oliveira, D. E. C. de; Resende, O.; Costa, L. M. Efeitos da secagem na coloração dos frutos de baru (Dipteryx alata Vogel). Revista Agro@mbiente On-line, v.10, p.364-370, 2017.

Rocha, L. S.; Santiago, R. de A. C. Implicações nutricionais e sensoriais da polpa e casca de baru (Dipterix alata Vog.) na elaboração de pães. Ciência e Tecnologia de Alimentos, v.29, p.820-825, 2009. https://doi.org/10.1590/S0101-20612009000400019

Sano, S. M.; Ribeiro, J. F.; Brito, M. A. Baru: Biologia e uso. Planaltina: Embrapa Cerrados, 2004. 52p.

Silva, F. P.; Siqueira, V. C.; Quinzani, G. A.; Martins, E. A. S.; Goneli, A. L. D. Drying kinetics of niger seeds. Engenharia Agrícola, v.37, p.727-738, 2017. https://doi.org/10.1590/1809-4430-eng.agric. v37n4p727-738/2017

Siqueira, V. C.; Resende, O.; Chaves, T. H. Difusividade efetiva de grãos e frutos de pinhão-manso. Semina: Ciências Agrárias, v.33, p.2919-2930, 2012. https://doi.org/10.5433/16790359.2012v33Supl1p2919
Smaniotto, T. A. de S.; Resende, O.; Sousa, K. A. de; Oliveira, D. E. C. de; Campos, R. C. Drying kinetics of sunflower grains. Revista Brasileira de Engenharia Agrícola e Ambiental, v.21, p.203-208, 2017. https://doi.org/10.1590/1807-1929/agriambi. v21n3p203-208

Sousa, E. P.; Figueirêdo, R. M. F. de; Gomes, J. P.; Queiroz, A. J. de M.; Castro, D. S. de; Lemos, D. M. Mathematical modeling of pequi pulp drying and effective diffusivity determination. Revista Brasileira de Engenharia Agrícola e Ambiental, v.21, p.493-498, 2017. https://doi.org/10.1590/1807-1929/agriambi. v21n7p493-498

Sousa, E. P. de; Queiroz, A. J. de M.; Figueiredo, R. M. F. de; Lemos, D. M. Comportamento reológico e efeito da temperatura da polpa de pequi em diferentes concentrações. Brazilian Journal Food and Technology, v.17, p.226-235, 2014. https://doi.org/10.1590/19816723.1214

Sousa, F. T.; Silva, M. A. P. da; Oliveira, D. E. C.; Plácido, G. R.; Gagnin, C.; Moura, L. C.; Souza, D. G.; Caliari, M.; Lima, M. S. Modelagem matemática da secagem e propriedades físicas e funcionais do bagaço de malte. Global Science and Technology, v.9, p.51-61, 2016. 